UDK 630*232.12(497.11)

Original scientific paper

\title{
MAGNESIUM CONCENTRATION IN THE CANADIAN DOUGLAS-FIR NEEDLES OF DIFFERENT PROVENANCES
}

\author{
Vera S. LAVADINOVIĆ' , Zoran MILETIĆl, Ljubinko RAKONJAC ${ }^{l}$, \\ Vukan M. LAVADINOVIĆ
}

\begin{abstract}
The morphology, anatomy, ecology and physiology of introduced tree species should be tested in order to confirm their autochthonous characteristics and justify their introduction. Douglas-fir (Pseudotsuga mensiesii Mirb/Franco) is a species with a very wide geographical range of distribution and an extensive altitudinal range. Its natural area of distribution stretches from New Mexico to Canada and from the Pacific to the Rocky Mountains. The species should be tested using the model of provenance tests in order to select the most adaptive and promising provenances to be introduced into new ecosystems of Serbia. This paper deals with the content of magnesium in the needles of Douglas-fir in different provenances originating from Canada. Magnesium is the most important mineral for all living organisms and affects a number of biochemical processes in plants.The research was carried out on fourteen different provenances of Douglas-fir originating from Canada on two different soil types - eutric cambisol and vertisol. All the trees of the study provenances were of the same age and grown under the same conditions on two different types of soil. The determined amounts of magnesium in the needles indicate that there are differences in the ability of certain provenances of Douglas-fir to absorb this element of nutrition from the soil.
\end{abstract}

Keywords: Douglas-fir, Provenances, Magnesium, Eutric Cambisol, Vertisol

\footnotetext{
${ }^{1}$ Institute of Forestry, Belgrade, Kneza Višeslava3, Serbia

${ }^{2}$ Faculty of Forestry ,University of Belgrade, Kneza Višeslava 1, Serbia

Email: veralava@eunet.rs
} 


\section{KONCENTRACIJA MAGNEZIUJUMA U ČETINAMA KANADSKE DUGLAZIJE RAZLIČITIH PROVENIJENCIJA}

Izvod: Introdukovane vrste drveća je potrebno morfološki, anatomski, ekološki i fiziološki testirati da bi se potvrdile njihove autohtone karakteristike $i$ opravdao cilj introdukcije. Douglas-fir (Pseudotsuga mensiesii Mirb/Franco) je vrsta sa vrlo širokim geografskim arealom i velikim rasponom nadmorske visine. Prirodni areal duglazije je od Novog Meksika do Kanade i od Pacifika do Stenovitih planina. Vrstu je potrebno testirati modelom provenijeničnog ogleda $i$ odabrati adaptivne $i$ perspektivne provenijencije za introdukciju u nove ekosisteme Srbije. Predmet istraživanja je sadržaj magnezijuma u četinama duglazije različitih provenijancija poreklom iz Kanade. Magnezijum je najvažniji mineral za sve žive organizme $i$ utiče na mnoštvo biohemijskih procesa u biljkama. Istraživanja su obavljena sa četrnaest različitih provenijencija duglazije poreklim iz Kanade, na dva različita tipa zemljišta eutričnom kambisolu $i$ vertisolu. Sva stabla ispitivanih provenijencija bile su iste starosti i uzgajane su pod istim uslovima na dve različite vrste zemljišta. Konstatovane količine magnezijuma u četinama ukazuju da postoje razlike u sposobnosti pojedinih provenijencija duglazije da usvaja ovaj element ishrane iz zemljišta.

Ključne reči: duglazija, provenijencija, magnezijum, eutrični kambisol, vertisol

\section{INTRODUCTION}

Its biological characteristics, economic advantages and ecological adaptability have made Douglas-fir a species suitable for introduction and consequently a topic of a great number of research studies (Apple, M., at al., 2002, Gutschick, V.P., 1999, Hermann, R. K., 1987, Hermann R. and Lavender D., 1990, Ian, F., 2001, Kleinschmit, J. and Bastien, Ch., 1992).

In Serbia, Douglas-fir has been introduced into quite different sites. Its monocultures have replaced natural forests from the submontane to the subalpine belt. Douglas-fir has often been used in the reclamation of coppice forests in Serbia. Douglas-fir plantations have replaced autochthonous coppice forests, most often in oak and beech belts.

The study of the changes in soil properties caused by the replacement of autochthonous coppice forests with Douglas-fir plantations has been performed at different sites in Serbia. Previous studies of the effects of Douglas-fir on the changes in soil properties after the replacement of autochthonous forests at different sites in Serbia have provided different results (Lavadinović V., Miletić Z. and Lavadinović V., 2015).

Nutrition is an essential segment in the growth of plants. Plants must consume sufficient quantities of microelements from the soil. Bioelements or biogenic elements are regularly present in the essential components of living organisms either in an inorganic or in an organic form. Apart from carbon, oxygen and hydrogen, the main nutrients of vital importance for plants are nitrogen, phosphorus, sulfur, potassium, calcium and magnesium.

Magnesium, calcium, and potassium are often referred to as macronutrients. Although in many organisms they make up only about $0.1 \%$ of organic matter, they are essential for vital life functions. 
Magnesium, as an essential component of chlorophyll (bound to nitrogen in the porphyrin core), is one of the minerals indispensable for the growth of plants. Its most important role is to build chlorophyll in the process of photosynthesis, but it also plays a prominent role in the processes in which it makes the synthesis of organic compounds that are useful for the growth and functioning of plants. It performs the synthesis of amino acids, pectin and cell proteins as well as the assimilation and movement of phosphorus in plants.

The deficiency of magnesium interrupts the process of photosynthesis and causes chlorophyll breakdown. It is manifested as chlorosis on the lower leaves (loss of green color between the vessels), with leaf edges bending upwards.

The excess of magnesium is also disadvantageous because it is toxic to plants, and the increased concentration of $\mathrm{Mg}$ can further lead to a decrease in $\mathrm{Ca}$ concentration in plants because these two elements are antagonistic. The leaves turn orange-red, wilt and fall off (Dubravka Steiner, Slavko Kevresan 2014).

\section{MATERIAL AND METHODS}

The Institute of Forestry in Belgrade has been carrying out provenance testing of Douglas-fir originating from Canada and America for more than 30 years (Lavadinović, V., et al., 2001, Lavadinović,V., et al., 2010, Lavadinović, V., et al. 2011, Lavadinović,V., et al 2011a, Lavadinović, S.,V., et al., 2011b, Lavadinović,V., et al 2011c, Lavadinović,V., et al., 2011d, Lavadinović,V., et al., 2014, Lavadinović, V., et al., 2015, Vera Lavadinović, et al., 2016).

The material used in this research included seedlings from two different sites (Arboretum of the Faculty of Forestry and a nursery in Sremčica near Belgrade) where provenance testing was carried out using 14 provenances of Douglas fir originating in Canada. Table 1 shows the geographical characteristics of the original seed used to produce the seedlings which served as material for the establishment of the experiment. (Lavadinović, S., V., et al., 2015a).

Table 1. Geographic characteristics of Douglas-fir test provenances in Canada

\begin{tabular}{|c|c|c|c|c|c|c|}
\hline \multicolumn{2}{|c|}{ Provenances } & \multirow{2}{*}{ Seed zone } & \multirow{2}{*}{ Location } & \multicolumn{2}{|c|}{ Geographical } & \multirow{2}{*}{ Altitude } \\
\hline No & Code & & & latitude & longitude & \\
\hline 1 & 03333 & East Kootenay & Cranbrook & $49^{0} 25^{\prime}$ & $115^{0} 20^{\prime}$ & $1050 \mathrm{~m}$ \\
\hline 2 & 00848 & West Kootenay & Inonoaklin & $49^{0} 50^{\prime}$ & $118^{0} 10^{\prime}$ & $671 \mathrm{~m}$ \\
\hline 3 & 30667 & Shuswap Adams & Mann Creek & $51^{0} 35^{\prime}$ & $120^{0} 10^{\prime}$ & $600 \mathrm{~m}$ \\
\hline 4 & 05227 & East Kootenay & Gavia Lake tfl 14 & $50^{0} 56^{\prime}$ & $116^{0} 35^{\prime}$ & $1070 \mathrm{~m}$ \\
\hline 5 & 05226 & East Kootenay & Nine Bay TFL 14 & $50^{0} 58^{\prime}$ & $116^{0} 32^{\prime}$ & $975 \mathrm{~m}$ \\
\hline 6 & 03356 & Thompson Okanagan Arid & Trout $\mathrm{Cr}$ & $49^{0} 40^{\prime}$ & $119^{0} 52^{\prime}$ & $884 \mathrm{~m}$ \\
\hline 7 & 03360 & Thompson Okanagan Arid & Michell $\mathrm{Cr}$ & $49^{0} 54^{\prime}$ & $119^{0} 37^{\prime}$ & $1035 \mathrm{~m}$ \\
\hline 8 & 01198 & West Kootenay & Salmo & $49^{0} 15^{\prime}$ & $117^{0} 30^{\prime}$ & $793 \mathrm{~m}$ \\
\hline 9 & 30460 & Shuswap Adams & Mara LK & $50^{0} 48^{\prime}$ & $119^{0} 00^{\prime}$ & $488 \mathrm{~m}$ \\
\hline 10 & 00278 & Thompson Okanagan Arid & Monte Crk & $50^{0} 37^{\prime}$ & $119^{0} 52^{\prime}$ & $701 \mathrm{~m}$ \\
\hline 11 & 03383 & West Wootenay & Sheep Creek & $49^{0} 10^{\prime}$ & $117^{0} 15^{\prime}$ & $1000 \mathrm{~m}$ \\
\hline 12 & 30461 & Shuswap Adams & Cooke Creek & $50^{0} 38^{\prime}$ & $118^{0} 49^{\prime}$ & $900 \mathrm{~m}$ \\
\hline 13 & 03389 & West Kootenay & Benton Creek & $49^{0} 12^{\prime}$ & $117^{0} 25^{\prime}$ & $933 \mathrm{~m}$ \\
\hline 14 & 05092 & East Kootenay & Sun Creek & $50^{0} 08^{\prime}$ & $115^{0} 52^{\prime}$ & $1000 \mathrm{~m}$ \\
\hline
\end{tabular}

Source: (Lavadinović V., et al 2015b) 
The distance between the sites where Douglas-fir seedlings of different provenances were produced is $20 \mathrm{~km}$, which implies that they were grown in approximately the same microclimate conditions. The Arboretum of the Faculty of Forestry has eutric cambisol type of soil, while Sremčica Nursery grows trees on vertisol. The seedlings were produced in containers, and at the age of 3 years $(3+0)$, they were transplanted into experimental plots with a distance of $2 \times 2 \mathrm{~m}$ per 60 plants from each provenance (Lavadinović, S., V., et al., 2015a).

At the age of 11, both sites had samples taken for foliar analysis. The needles required for laboratory analysis were sampled from the upper third of the crown of dormant seedlings. Only the current year needles were sampled. The samples collected were dried to an oven-dry state and then burnt in platinum crucibles, converting the ash into chlorides, and determining the amount of magnesium by complexometric titration.

The standard deviation of each individual value of the magnesium content in Douglas-fir needles was calculated according by the following formula:

$$
Z=\frac{M g-\overline{M g}}{\sigma}
$$

Where:

$\mathrm{Mg}$ - concentration of magnesium in the needles of each individual provenance, $\overline{M g}$ - the mean value of magnesium in the needles of all provenances on a given type of soil,

$\sigma$ - standard deviation.

\section{RESULTS AND DUSCISSIONS}

The results of the study point to considerable variability in the magnesium content in the needles of Douglas-fir of different provenances originating from Canada under the same site conditions (Table 2, Graph 1).

Table 2. The content of magnesium in the needles of Douglas-fir *

\begin{tabular}{|c|c|c|c|c|}
\hline & \multicolumn{2}{|c|}{ Locality of Sremčica - vertisol } & \multicolumn{2}{c|}{ Locality of the Arboretum-eutric cambisol } \\
\hline No. of provenance & $\mathrm{Mg}(\%)$ & $\mathrm{Z}$ & $\mathrm{Mg}(\%)$ & $\mathrm{Z}$ \\
\hline \hline 1 & 0.109 & 0.8723 & 0.181 & -0.9041 \\
\hline 2 & 0.132 & 0.3048 & 0.263 & -2.9037 \\
\hline 3 & 0.099 & 1.1143 & 0.187 & -1.0329 \\
\hline 4 & 0.129 & 0.3868 & 0.131 & 0.3351 \\
\hline 5 & 0.165 & -0.5017 & 0.139 & 0.1236 \\
\hline 6 & 0.116 & 0.6883 & 0.176 & -0.7741 \\
\hline 7 & 0.145 & -0.0082 & 0.158 & -0.3339 \\
\hline 8 & 0.129 & 0.3869 & 0.131 & 0.3396 \\
\hline 9 & 0.132 & 0.3131 & 0.186 & -1.0093 \\
\hline 10 & 0.088 & 1.3764 & 0.135 & 0.2299 \\
\hline 11 & 0.060 & 2.0599 & 0.139 & 0.1361 \\
\hline 12 & 0.085 & 1.4514 & 0.175 & -0.7606 \\
\hline 13 & 0.131 & 0.3319 & 0.196 & -1.2648 \\
\hline 14 & 0.145 & -0.0142 & 0.183 & -0.9431 \\
\hline \hline Average & 0.119 & & 0.170 & \\
\hline S & 0.0271 & & 0.0344 & \\
\hline Max & 0.165 & & 0.263 & \\
\hline Min & 0.060 & & 0.131 & \\
\hline
\end{tabular}




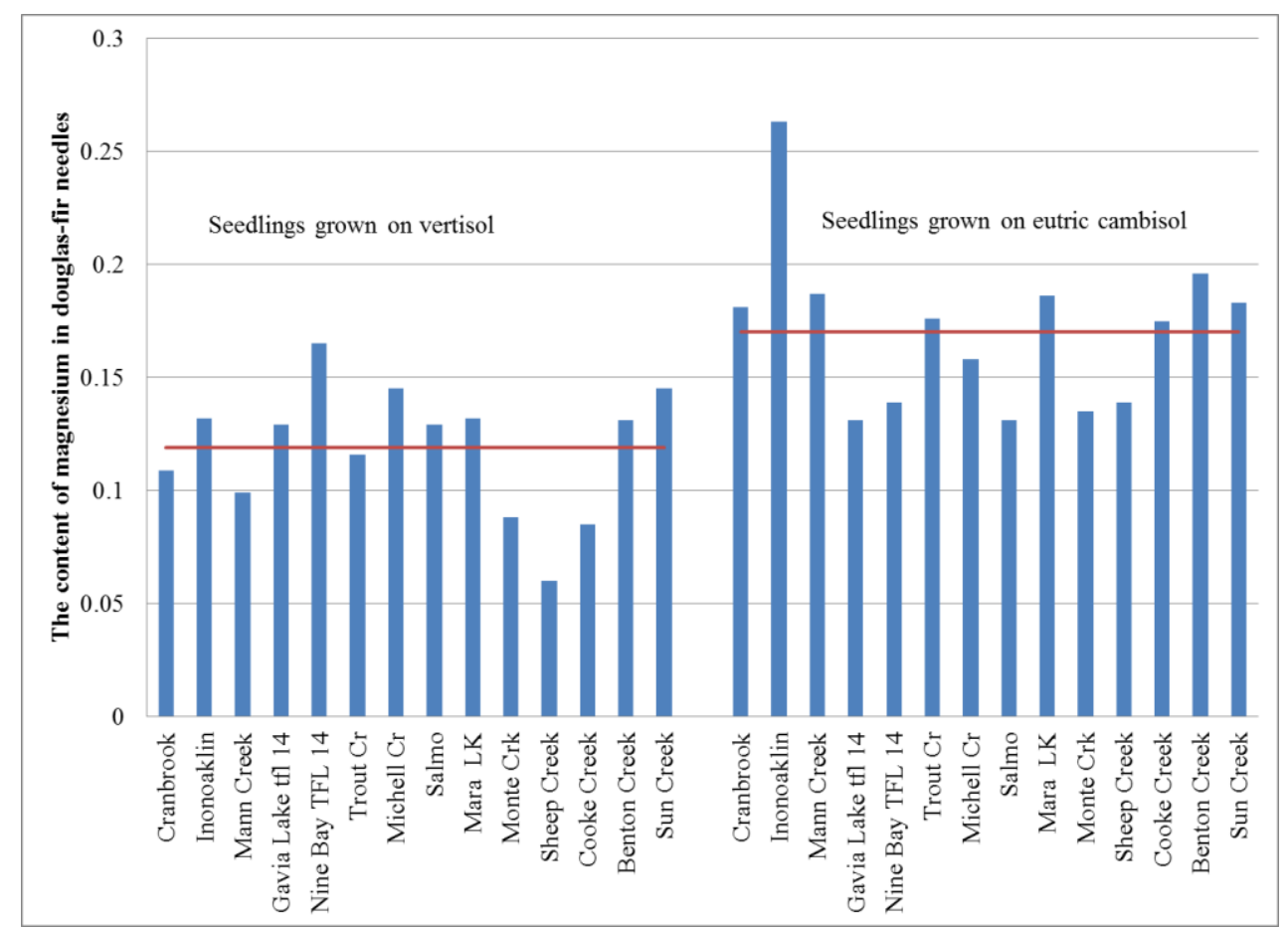

Graph 1. The content of magnesium in the needles of Douglas-fir grown on vertisol and eutric cambisol

The same results were obtained by testing the content of magnesium in the needles of Douglas-fir originating from the United States (Lavadinović, et al., 2011b).

Foliar analysis revealed a significantly lower content of magnesium in the needles of Douglas-fir trees grown on vertisol than in the provenances grown on eutric cambisol. The statistical significance of the difference in the magnesium content of the needles of Douglas-fir trees grown on these two types of soil is at the significance threshold of $1 \%$ Table 3 ).

Table 3. $t$-test values

\begin{tabular}{|c|c|c|c|c|c|}
\hline $\begin{array}{c}\text { The amount of Mg in the needles of } \\
\text { Douglas-fir on }\end{array}$ & mean & $\mathrm{N}$ & $\sigma$ & t-value & $\mathrm{p}$ \\
\hline Vertisol & 0.118929 & 14 & 0.028089 & \multirow{2}{*}{4.20783} & \multirow{2}{*}{0.000271} \\
\hline Eutric cambisol & 0.170000 & 14 & 0.035685 & & \\
\hline
\end{tabular}

Regarding vertisol, the highest concentrations of magnesium were found in the needles of provenance 5226 from the site of Nine Bay TFL 14 in East Kootenay seed zone. It was followed by provenances 03360 and 05092 whose natural sites are Michell $\mathrm{Cr}$ in Thompson Okanagan Arid seed zone and Sun Creek in East Kootenay seed zone. The lowest concentrations of magnesium in the needles of different provenances of Douglas-fir grown on vertisol were found in provenance 3383, whose natural site is Sheep Creek in West Wootenay seed zone. 
Very low amounts of magnesium were also found in provenances 00278 and 30461. The natural site of provenance 00278 is Monte Crk in the seed zone of Thompson Okanagan Arid, while provenance 30461 originates from Cooke Creek in Shuswap Adams seed zone.

By analyzing the multiple regression results (Table 4), it can be concluded that geographical characteristics of natural sites of the tested Douglas-fir provenances originating from Canada (geographical latitude, geographical longitude and altitude) have no effects on the concentrations of magnesium in the needles of Douglas-fir trees.

Table 4. Multiple correlations of the content of magnesium in Douglas-fir needles to geographical characteristics of natural provenance sites on eutric cambisol

\begin{tabular}{|l||c|c|c|c|c|c|c|}
\hline $\mathrm{R}=0.32157809 \mathrm{R}^{2}=0.10341247$ Adjusted $\mathrm{R}^{2}=$-.-- $\mathrm{F}(3.10)=.38447$ & $\mathrm{p}<.76658$ Std. error of estimate: 0.03033 \\
\hline $\mathrm{N}=14$ & Beta & $\begin{array}{c}\text { Std. Err. } \\
\text { of Beta }\end{array}$ & $\mathrm{B}$ & $\begin{array}{c}\text { Std. Err. } \\
\text { of B }\end{array}$ & $\mathrm{t}(10)$ & $\mathrm{p}$-level \\
\hline Independent variable & & & 0.470528 & 0.981587 & 0.479354 & 0.641997 \\
\hline Latitude & 0.190702 & 0.323954 & 0.006905 & 0.011730 & 0.588669 & 0.569141 \\
\hline Longitude & -0.332015 & 0.379813 & -0.005882 & 0.006729 & -0.874154 & 0.402540 \\
\hline Altitude & -0.027335 & 0.391871 & -0.000004 & 0.000060 & -0.069756 & 0.945763 \\
\hline
\end{tabular}

Regarding eutric cambisol, the highest concentrations of magnesium in assimilation organs were found in provenance 00848 from Inonoaklin site in West Kootenay seed zone, followed by provenance 03389 from Benton Creek site in the same seed zone.

The smallest amounts of magnesium in needles of the study provenances grown on eutric cambisol were found in provenance 05227 from Gavia Lake tfl 14 site in East Kootenay seed zone and provenance 01198 from Salmo site in East Kootenay seed zone.

As with the provenances of Douglas-fir grown on vertisol, the analysis of the multiple regression conducted for the provenances grown on eutric cambisol (Table 5) found that geographical characteristics of their natural sites have no effect on the concentration of magnesium in assimilation organs.

Table 5. Multiple correlations of the content of magnesium in Douglas-fir needles to geographical characteristics of natural provenance sites on vertisol

\begin{tabular}{|c|c|c|c|c|c|c|c|}
\hline $\mathrm{R}=.48062253 \quad \mathrm{R}^{2}=.23099801$ & Adjusted $\mathrm{R}^{2}=.00029742$ & $\mathrm{~F}(3.10)=1.0013$ & $\mathrm{p}<.43182$ & \multicolumn{2}{c|}{ Std.Error of estimate: .03568} \\
\hline $\mathrm{N}=14$ & Beta & $\begin{array}{c}\text { Std. Err. } \\
\text { of Beta }\end{array}$ & $\mathrm{B}$ & $\begin{array}{c}\text { Std. Err. } \\
\text { of B }\end{array}$ & $\mathrm{t}(10)$ & $\mathrm{p}$-level \\
\hline Independent variable & & & 1.451464 & 1.154885 & 1.25680 & 0.237388 \\
\hline Latitude & $-0,247753$ & 0.300020 & -0.011397 & 0.013801 & -0.82579 & 0.428187 \\
\hline Longitude & $-0,229149$ & 0.351753 & -0.005158 & 0.007917 & -0.65145 & 0.529443 \\
\hline Altitude & $-0,604666$ & 0.362920 & -0.000117 & 0.000070 & -1.66612 & 0.126659 \\
\hline
\end{tabular}




\section{CONCLUSION}

Based on the research carried out within provenance testing of 14 different provenances of Douglas-fir originating from Canada, it can be concluded that there is considerable variability in the content of magnesium in Douglas-fir needles. According to the results of the research conducted on two sites on vertisol and eutric cambisol, it can be concluded that the content of magnesium in the needles of Douglas-fir trees grown on vertisol is lower than the content of the provenances grown on eutric cambisol and that geographical characteristics of the natural sites of the tested provenances of Douglas-fir originating in Canada (latitude, longitude, and altitude) have no effect on the concentrations of magnesium in Douglas-fir needles. In the case of magnesium concentrations in Douglas-fir needles, the differences between certain provenances are genetic, which means that in the selection of provenances suitable for introduction, the genetic quality of Douglasfir must be taken into account. Genetic quality and the method of ecological selection confirm the adaptability and productivity of introduced species. Therefore, the genetic quality is an inevitable factor in the process of introduction.

Acknowledgment: This paper was realized as a part of the project 'The development of technological processes in forestry in order to realize the optimal forest cover' (TR31070), financed by the Ministry of Education and Science of the Republic of Serbia within the framework of integrated and interdisciplinary research for the period 2011-2017.

\section{REFERENCES}

Apple, M., Tiekotter, K., Snow M., Young, J., Soeldner, A., Phillips, D., Tingey D., Bond B.,J. (2002): Needle anatomy changes with increasing tree age in Douglas-fir. Tree Physiology 22, 129-136. 2002. pp. 129-136. Heron Publishing - Victoria, Canada

Gutschick, V.P. (1999). Biotic and abiotic consequences of differences in leaf structure, New Phytol. 143:3-18.

Hermann, Richard K. (1987). North-American tree species in Europe. Journal of Forestry 85 (12):27-32.

Hermann R and Lavender D (1990) Pseudotsuga menziesii (Mirb.) Franco. In: Burns RM and Honkala BH (eds) Silvics of North America. Vol I. Conifers. Agriculture Handbook 654, pp 522-540. US Department of Agriculture Forest Service, Washington, DC

Ian Forrest, Helen Tabbener, Joan Cottrell, Tom Connolly (2001): The genetic structures of a range of Douglas-fir provenance collections after planting in different European countries, assessed with two biochemical marker systems. Biochemical Systematics and Ecology.Volume 29, Issue 8, August 2001, Pages 769-792

Lavadinović, V., Isajev, V., Koprivica, M. (2001): Influence of provenances gene pool of Douglas-fir on height increment of trees in experimental test in East Serbia. Genetics, Vol. 33, No. 1-2, pp. 11-17, Belgrade. 
Lavadinović,V., Isajev,V., Miletić,Z.(2010): Significance of Genetic Potential of Douglasfir Introduced Provenances In Serbia For The Ranking of Their Adaptation to Climate Changes. IUFRO and EFI International scientific conference; 'Forest ecosystems and climate changes`. Plenary lectures. ISBN 978-86-80439-20-4. Pp 71-80. Belgrade, 9-10 March, Serbia

Lavadinović Vera, Miletić Zoran, Isajev Vasilije, Krstć Milun (2011): Variability Of Nitrogen Content In The Needles Of Douglas-Fir Provenance (Pseudotsuga menziesii Mir / Franco) Genetics, Vol. 43, No2 (2011). Serbian Genetics Society. ISSN 0534-0012. pp. 407-417. UDC 575:630. DOI: 10.2298/GENSR1102407L. Serbia

Lavadinović,V., Miletić, Z., Isajev,V., Krstć,M. (2011a): Variability of nitrogen content in the needles of Douglas-fir provenance (Pseudotsuga Menziesii Mir / Franco), Genetics, Vol. 43, No 2 (2011). pp. 407-417, UDC 575:630. DOI: 10.2298/GENSR1102407L.

Lavadinović, S.,V., Miletić, Z., Lavadinović, M.,V., Isajev, V. (2011b): Variability In Magnesium Concetration In Needles Of Different Douglas-Fir Provenances. Journal : Forestry Ideas, 2011, Vol. 17, No. 1. UDC 581.4. pp.74-79. Sofia, Bulgaria.

Lavadinović,V., Isajev,V., Miletić,Z. (2011c): Ecological adaptibility of Douglas-fir provenances in Serbia. First Serbian Forestry Congress: 'Future with Forests' 11-13 November, 2010. Faculty of Forestry, University of Belgrade. ISBN 978-86-7299-0713.COBISS-ID 182189580. Pp 312-319

Lavadinović,V., Miletić,Z., Isajev,V., Rakonjac,Lj., Lučić,A. (2011d): Variability of phosphorus content in the needles of different Douglas-fir provenances. Proceedings of the Biennial International Symposium. Forest and Sustainable Development, 'Transilvania' University of Brasov, ISSN 1843-505X. Faculty of Silviculture and Forest Engineering. Brasov 15-16 October, 2010 Romania. pp. 47-52

Vera Lavadinović, Vukan Lavadinović, Ilija Djordjević (2015): Variability of seedlings of Douglas-fir provenances introduced from Canada. Genetics, UDC 575:630, DOI: 10.2298/GENSR1503079L:1079-1090

Lavadinović, S., V., Miletić Z. and Lavadinović M., V. 2015a). Variability of nitrogen and carbon contents in the needles of Canadian Douglas-Fir provenances on two soil types in Serbia. Baltic Forestry, Vol. 21, No 2 (41): 272-278.ISSN 2029-9230

Vera Lavadinović, Vukan M. Lavadinović, Zoran Poduška and Ilija Đorđević, 2015b: Correlation between seedling length and Canadian Douglas-fir height. Archives of Biological Sciences, 2015 67(4):1251-1255. DOI: 10.2298/ABS150323101L

Dubravka Štajner, Slavko Kevrešan (2014). Chemistry, Faculty of Agriculture, (Novi Sad: FB print). - 303 str. : illustr. ISBN 978-86-7520-313-1- Edition of basic student`s books, COBISS.SR-ID 290315271.The Library of Matica Srpska, Novi Sad. 


\title{
MAGNESIUM CONCENTRATION IN THE CANADIAN DOUGLAS-FIR NEEDLES OF DIFFERENT PROVENANCES
}

\author{
Vera S. LAVADINOVIĆ, Zoran MILETIĆ, Ljubinko RAKONJAC, \\ Vukan M. LAVADINOVIĆ
}

\begin{abstract}
Summary
Biogenic elements are the most important chemical cell elements needed for the growth and development of all living organisms. The magnesium has multiple roles in the functioning of plants. As a mineral essential for the growth of plants, it plays an important role in chlorophyll building during the process of photosynthesis. It is an integral part of the chlorophyll molecule. It also ensures the movement of phosphorus, the concentration of vitamins $\mathrm{A}$ and $\mathrm{C}$, the synthesis of amino acids and cell proteins. The amounts of magnesium in needles reveal the potentials of certain provenances of Douglas-fir to adopt this element of nutrition from the soil. Doulas-fir is a coniferous species with a wide range of natural distribution in North America (from New Mexico to Canada). Therefore, it is necessary to conduct provenance tests before introduction programs are implemented. The paper studied the concentration of magnesium in the needles of Douglas-fir (Pseudotsuga mensiesii / Mirb./ Franco) in the tests conducted at two sites under homogeneous site conditions. Based on the research carried out in the provenance test with 14 different provenances of Douglas-fir originating from Canada, it can be concluded that there is considerable variability in the content of magnesium in Douglas-fir needles. The results of the research conducted at two sites on vertisol and eutric cambisol determined a lower content of magnesium in the needles of Douglas-fir trees grown on vertisol than in the provenances grown on eutric cambisol. The results further point that geographical characteristics of the natural sites of the investigated provenances of Douglas-fir originating from Canada (latitude, longitude and altitude) do not affect the concentration of magnesium in the needles of Douglas-fir. In the case of magnesium concentrations in Douglas-fir needles, the differences between certain provenances are genetic, which means that in the selection of provenances suitable for introduction, the genetic quality of Douglas-fir must be taken into account. Genetic quality and the method of ecological selection confirm the adaptability and productivity of introduced species. Therefore, the genetic quality is an inevitable factor in the process of introduction.
\end{abstract}

\section{KONCENTRACIJA MAGNEZIUJUMA U ČETINAMA KANADSKE DUGLAZIJE RAZLIČITIH PROVENIJENCIJA}

\author{
Vera S. LAVADINOVIĆ, Zoran MILETIĆ, Ljubinko RAKONJAC, \\ Vukan M. LAVADINOVIĆ
}

\section{Rezime}

Biogeni elementi su najvažniji hemijski elementi ćelija, neophodnih za rast i razvoj svih živih organizama. Uloga magnezijuma u funkciji biljaka je višestruka. Kao neophodan mineral za razvoj biljaka ima bitnu ulogu u izgradnji hlorofila u procesu fotosinteze. Sastavni je deo molekula hlorofila. Takodje obezbedjuje, kretanje fosfora, koncentraciju vitamina A i $\mathrm{C}$, sintezu aminokiselina i ćelijskih proteina. Utvrđivanje količine magnezijuma u četinama, indikativne su za različite mogućnosti određenih provenijencija duglazije za usvajanje ovog nutritivnog elementa iz zemlje. Duglazija je vrsta četinara sa žirokim prirodnim arealom u Severnoj Americi (od Novog Meksika do 
Kanade), pa je neophodno sprovoditi oglede putem provenijeničnog testa pre programa introdukcije. U radu je ispitivana koncentracija magnezijuma u četinam duglazije (Pseudotsuga mensiesii / Mirb./ Franco) u ogledima na dva lokaliteta pod homogenim uslovima na terenu. $\mathrm{Na}$ osnovu ispitivanja provedenih u sklopu testa sa 14 različitih provenijencija duglazije, porekom iz Kanade, može se zaključiti da postoje izražene varijabilnosti sadržaja magnezijuma u četinama duglazije. Na osnovu rezultata istraživanja sa dva lokaliteta na vertisolu i eutričnom kambisolu konstatovan je znatno manji sadržaj magnezijuma u četinama duglazije odgajenih na vertisolu u odnosu na provenijencije odgajene na eutričnom kambisolu, kao i da geografske karakteristike prirodnih nalazišta ispitivanih provenijencija duglazije poreklom iz Kanade ( geografska širina, geografska dužina inadmorska visina) nemaju uticaja na koncentraciju magnezijuma u četinama duglazije. U slučaju koncentracije magnezijuma u četinama duglazije, razlike između određenih provenijacija su genetski preduslovljene. Što znači da pri izboru provenijencije pri introdukciji mora se voditi računa o genetskom kvalitetu duglazije. Genetski kvalitet i ekolološki selekcioni metod potvrdjuje adaptivnost i produktivnost introdukovanih vrsta i neizbežan je faktor pri introdukciji. 